\title{
The Protection of Cultural Heritage and International Commerce
}

\author{
Kurt Siehr*
}

\section{Introduction}

International commerce of cultural objects faces problems because national rules differ with respect to transactions concerning movable property in general and, especially, with regard to cultural objects.

In all countries stealing is a crime. Therefore, the acquisition of title to property by theft is forbidden. National rules, however, differ in at least three respects: first, stolen property may be acquired bona fide; second, a bona fide purchaser may be protected by acquisitive prescription, and, third, there may be certain time limitations to a claim for the recovery of stolen objects.

In many jurisdictions cultural objects enjoy specific legal regimes distinct from movables in general. Cultural objects may be qualified as inalienable (res extra commercium) or as objects of public property (domaine public, demanio pubblico). Cultural objects, even if treated as normal movables in domestic commerce, may be burdened by special rules for international commerce. For example, as objects of national cultural heritage, their export without an official permission may be forbidden.

The conflicting national policies which clash in international transactions may be solved by different sets of rules: multilateral conventions; bilateral treaties; supranational law, which may be either directly applicable or indirectly applicable only in the form of harmonized national law; international customary law, and national rules of private international law. As will be seen, most of these sources are not common to all jurisdictions. Therefore, even the same problem may have different solutions in different countries.

\section{International Commerce in Stolen or Illegally Excavated Cultural Objects}

\subsection{Examples}

In 1911, Leonardo da Vinci's Mona Lisa (La Gioconda) was stolen from the Louvre in Paris and later discovered in Florence. ${ }^{1}$ The

* Professor of Law, University of Zürich, Switzerland. 
painting was given back, and the only court proceeding was the criminal trial of the thief Vincenzo Peruggia in Florence. ${ }^{2}$

What was easy in the case of a famous and therefore unmerchantable painting may create problems with respect to less well known cultural objects. The defendant who is sued for return of an object may raise two objections: bona fide purchase and lapse of time. In another Italian case, the defendant De Contessini was sued for the return of tapestries stolen in France (Riom), and he successfully objected that he had bought the tapestries bona fide in Italy and therefore, according to Italian law, was entitled to keep them. ${ }^{3}$ In an American case, the original owner could not recover a stolen painting of Claude Monet because she did not bring her replevin suit in time. The court based its holding on the fact that the owner had been negligent in tracing the whereabouts of her stolen painting. ${ }^{4}$

Treasure hunting, tomb robbery and illegal excavations have had a long history of providing cultural objects for international trade. The objects of these activities were and still are intended to be sold to collectors, museums and art dealers. Many cases have occurred in which archaeological objects found in Mediterranean countries surfaced in Germany (ancient coins ${ }^{5}$ ), Switzerland (Etruscan tomb stones, ${ }^{6}$ Turkish grave stelai ${ }^{7}$ ), the United Kingdom (Apulian vases $^{8}$ ), and the Unites States (Pre-Columbian artifacts, ${ }^{9}$ the Lydian hoard ${ }^{10}$ and the Sevso treasure ${ }^{11}$ ). In many of these cases, the cultural objects had to be returned if the plaintiff or the applying party could prove the source. However, apart from difficulties as to factual matters, several legal problems need to be solved in order to provide effective protection against the theft and trade of cultural objects.

\subsection{Solutions by national rules of international commerce}

Suits for recovery of stolen cultural objects are generally brought to court in the place where the objects have been found. If no international treaties or conventions govern in the forum state, national rules of international commerce apply. Four different rules must be distinguished: 1) rules governing bona fide purchase; 2) rules governing lapse of time; 3 ) rules regarding commerce in stolen objects; and 4) rules determining State property or preemptive rights.

\subsubsection{Law applicable to bona fide purchase}

Several countries provide in their civil codes or statutes for a bona fide purchase of goods not belonging to the seller. According to such rules on bona fide purchase, the buyer will become the owner of the sold object and the owner will be deprived of his title if the buyer did not know and, as a diligent buyer, could not know that the sold object did not belong to the seller. As such, a bona fide purchase is 
not known everywhere and, if known, not valid to the same extent. It therefore matters which law applies with respect to such a transaction.

Whether title to a stolen movable object can be acquired through bona fide purchase is governed by the law of the State in which the movable was located at the time of the alleged bona fide purchase. This rule of private international law is almost universally accepted ${ }^{12}$ and is known as the rule of lex rei sitae. This rule implies that once a movable object has been acquired bona fide, this acquisition is a vested right and will be protected as such even if the location of the movable changes in the future.

The principle of lex rei sitae was confirmed by the English court decision Winkworth v. Christie, Manson \& Woods Ltd. ${ }^{13}$ The plaintiff's Japanese drawings were stolen in England and sold in Italy to a bona fide purchaser. The purchaser gave them to Christie's in London to be sold at public auction. The plaintiff got notice of the scheduled auction of his drawings and sued Christie's for recovery of his property. The court dismissed the suit because the Italian bona fide purchase transferred good title to the purchaser. The title was valid in England as a vested right and could not be denied successfully by the former owner. It is likely that the same decision would have been handed down by Austrian, ${ }^{14}$ Dutch, ${ }^{15}$ German, ${ }^{16}$ Italian, ${ }^{17}$ Swedish, ${ }^{18}$ Spanish $^{19}$ and Swiss courts. ${ }^{20}$

\subsubsection{Law applicable to prescription, statutes of limitation and laches}

Even if there is no rule of bona fide purchase, as in the United States and the United Kingdom, the original owner may by precluded from reclaiming a stolen movable if suit is not brought in time. Such time limitations may be a sword in the hands of the plaintiff alleging that by lapse of time and acquisitive prescription he has become the owner as a bona fide purchaser. On the other hand, the defendant may use time limitations as a shield and raise the defense that the plaintiff did not bring his recovery claim in time and is therefore precluded from doing so after the expiration of the applicable time limit. As every country has its own rules for designating the applicable law, the issue may be decided differently in fora of different countries.

Most civil law countries provide acquisitive prescription as the modern form of the Roman law of usucapio and also the normal statutes of limitations. In common law countries, different rules apply for the preclusion of a stale claim. In addition to the statute of limitations, the owner may be precluded by estoppel, laches or prescription from reclaiming his cultural objects.

Whether such time limits apply is decided according to different conflicts rules. While some jurisdictions apply the lex fori as the law governing procedure and time limits for the foreclosure of reme- 
dies, ${ }^{21}$ most Continental European countries apply the law of the State where the movable is located (lex rei sitae). ${ }^{22}$ If the law fixes a certain time for acquisitive prescription, any time lapsed under a previous lex rei sitae is added to the fixed time period.

Examples of time limit rules are illustrated by the following two cases. In the American case De Weerth v. Baldinger, the plaintiff sued for the return of a painting of Claude Monet, which was stolen in Germany in $1945 .^{23}$ The plaintiff's claim failed when the court determined that she did not search diligently for the painting and she was thereby precluded from recovering from the bona fide purchaser. In a Swiss case, the former owner of paintings allegedly confiscated by Nazi authorities brought suit against the purchaser of these paintings. Declining to base its decision on bona fide purchase, the court relied on acquisitive prescription rules (Ersitzung) and decided against the plaintiff. ${ }^{24}$ The defendants acted bona fide when taking possession of the paintings and the Swiss time period of five years had already elapsed. Hence, the claim for recovery was precluded and the action was dismissed.

\subsubsection{Prohibition on dealing in stolen property}

Under American federal law, it is prohibited to sell or dispose "of any goods, wares, merchandise, securities or money, of the value of $\$ 5,000$ or more which have crossed a State or United States boundary after being stolen, unlawfully converted or taken, knowing the same to have been stolen, unlawfully converted or taken. ..."25 This provision has been applied to cultural objects. ${ }^{26}$

\subsubsection{Exercise of State right of preemption or acquisition}

If archaeological treasures are not ipso facto state property (as, for example, in Greece ${ }^{27}$ and Italy $^{28}$ ), some jurisdictions provide that the State may exercise a right to acquire them from the private owner. ${ }^{29}$ Such a right can only be exercised so long as the object is located within the State exercising the forced taking of private property. ${ }^{30}$

\subsubsection{Intermediate summary}

Under national law, unregulated by international or supranational instruments, the protection of cultural property is governed by the rule of the weakest provision. If national rules differ, the rule protecting the bona fide purchaser or possessor prevails and not the rule most favourable to the former owner. In short, international commerce is given precedence over preservation of the original status quo unless national rules prohibit all transactions in stolen property. 
2.3 Solutions by European law of international commerce

There are no common European rules on stolen cultural property, neither rules of substantive law nor conflicts rules. European law deals only with illegally exported or removed cultural objects (infra at $\S 3.3$ ). Hence, European law applies to stolen cultural objects only if they were illegally removed from the territory of a Member State

- either before or after a theft.

\subsection{Solutions by international conventions on international commerce}

\subsubsection{Hague Regulations and Conventions}

Under the Hague Convention of $1907,{ }^{31}$ looting during times of war is unlawful. The same rule was laid down in the Hague Convention of 1954 for the Protection of Cultural Property in the Event of Armed Conflict. ${ }^{32}$ Whether these provisions are very effective is questionable. The destructions suffered during the war in Yugoslavia are not very encouraging.

\subsubsection{UNESCO Convention of 1970}

The UNESCO Convention of November 14, 1970 on the Means of Prohibiting and Preventing the Illicit Import, Export and Transfer of Ownership of Cultural Property ${ }^{33}$ is not self-executing. According to Article 7 (b)(I), all States Parties undertake "to prohibit the import of cultural property stolen from a museum or a religious or secular public monument or similar institution in another State Party ... provided that such property is documented as appertaining to the inventory of that institution." The United States is one of a very few nations which has implemented this treaty and has provided accordingly that no stolen cultural property may be imported into the United States. ${ }^{34}$

\subsubsection{Unidroit Convention of 1995}

The Unidroit Convention of June 24, 1995 on Stolen or Illegally Exported Cultural Objects, ${ }^{35}$ although not yet in force, also "applies to claims of an international character for the restitution of stolen cultural objects" (Article 1 lit. a). According to Article 3 of the Convention, every cultural object, as defined by Article 2 and the Annex to the Convention, must be returned to the owner if the claim for restitution is brought in time. Unlawfully excavated or lawfully excavated but unlawfully retained cultural objects are considered to be stolen when consistent with the law of the State where the excavation took place (Article 3 (2)). There is no bona fide transfer of title in foreign cultural property. The bona fide purchaser is, however, entitled to "payment of fair and reasonable compensation" (Article 4). 
The Unidroit Convention fixes time limits for the claim for restitution (Article 3 (3) - (5)) and does not oblige the Contracting States to apply the Convention retroactively (Article 10). However, it does not answer three basic questions: Who is entitled to bring a claim for restitution? What is "reasonable restitution"? What is a claim of "international character"? The last question is very important in order to delimit the application of national law from the obligations under the Unidroit Convention.

If the Unidroit Convention were applied retroactively, the Italian case $D e$ Contessini ${ }^{36}$ would have been decided differently. The Italian court could not have admitted the defendant's defense of bona fide purchase. A similar outcome would have occurred in the English Winkworth case $^{37}$ if the English owner had brought a claim of restitution against the bona fide purchaser in Italy. In the case itself, however, the cultural object was located in the country where it had been stolen and where the plaintiff was domiciled. In this situation, English courts do not need any convention in order to protect its national treasures. The court could have disregarded the English conflicts rule on the protection of vested rights acquired by a bona fide purchase which occurred abroad under the foreign lex rei sitae. ${ }^{38}$ In summary, a claim for the restitution of stolen property has an international character if suit is brought by an owner domiciled abroad and the bona fide purchase occurred outside the place of the plaintiff's domicile.

This implies that the Unidroit Convention of 1995 does not abolish rules on bona fide purchase of cultural objects traded in their country of origin. If the objects of the Winkworth case were of Italian origin, stolen in Italy at the owner's place of domicile, acquired bona fide in Italy, and removed to England for auction, the former owner could not avail himself of the Unidroit Convention and recover the objects in England.

\subsubsection{Conventions on Legal Assistance in Matters of Criminal Law}

According to several multilateral and bilateral international instruments on legal assistance in matters of criminal law, ${ }^{39}$ member States may ask for the transmission of stolen objects as pieces of evidence. Such a transmission, however, is only temporary because the objects have to be returned after the criminal trial..$^{40}$

An exception applies for objects still held by the thief and not yet acquired bona fide by a purchaser. In this case, the requesting State may ask for the restitution of the object as objectum sceleris. This worked in a German case when Greece asked for the return of ancient coins excavated in Greece by a Greek landowner and exported to his place of domicile in Germany. ${ }^{41}$ The coins were State property according to the Greek law of antiquities. ${ }^{42}$ This rule of property law was recognized in Germany and the holder of the coins could be tried for conversion for State property. 


\subsubsection{Council of Europe, International Law Association, and Institute of International Law}

The Council of Europe has prepared several conventions which are not self-executing on the problems of cultural property. The most recent instrument is the European Convention of 16 January 1992 on the Protection of the Archaeological Heritage. ${ }^{43}$ According to this Convention, already in force but not yet implemented by the States parties, ${ }^{44}$ each party agrees "to take such steps as are necessary to ensure that museums and similar institutions whose acquisition policy is under State control do not acquire elements of the archaeological heritage suspected of coming from uncontrolled finds or illicit excavations or unlawfully from official excavations." 45

The International Law Association (ILA) has, by its Committee on Cultural Property, prepared a draft Convention on the Protection of the Underwater Cultural Heritage. ${ }^{46}$ This draft is intended to ensure that underwater cultural heritage is protected under State control and that underwater finds are not circulated unlawfully. ${ }^{47}$

The Institute of International Law, ${ }^{48}$ at its session in Basle, adopted a resolution on "The international sale of works of art from the angle of the protection of the cultural heritage." 49 This resolution relates to sales of cultural property concluded before or after an illegal export. Such a transfer is governed by the law of the country of origin of the sold work of art including the export provisions of this country. If this resolution had been applied to the Italian-French case De Contessini ${ }^{50}$ (stolen French tapestries forming part of the French cultural heritage which were sold in Italy to a bona fide purchaser), the French State as the plaintiff would have succeeded. French law, as the law of the country of origin, would have governed the case and, according to French law, the tapestries as domaine public were unmerchantable and could not be transferred by sale.

\subsection{Solutions by international codes of conduct}

Many museums, galleries and auction houses have voluntarily obliged themselves to respect certain rules of professional ethics when buying, selling or exhibiting works of art. According to some of these codes of conduct, the trade in stolen or illegally excavated works of art is prohibited. ${ }^{51}$ The application of such codes of conduct may lead to the return of cultural objects.

\subsection{Intermediate summary}

There are no universal rules on the sale and transfer of cultural objects. National rules govern these transactions. International conventions are either not self-executing or not ratified or implemented in all countries. Therefore, the success of many proceedings depends on the rules of private international law of the forum state and the 
attitude of the national law governing the international trade in cultural objects. The Unidroit Convention of 1995 could alter this situation decisively.

\section{International Commerce in Illegally Exported or Unlawfully Removed Cultural Objects}

\subsection{Examples}

Many States prohibit the export of cultural objects unless permitted by government licence. ${ }^{52}$ Despite such export bans, cultural objects have been and still are smuggled. Earlier in the 19th century, the illegal export of cultural objects flourished in Italy. ${ }^{53}$ Currently, there are many court proceedings for the return of illegally exported cultural objects that have been initiated in several countries. New Zealand tried unsuccessfully in British courts to recover unlawfully exported Maori carvings; ${ }^{54}$ the Kingdom of Spain successfully applied for a declaration that Goya's painting The Marquesa de Santa Cruz had been exported from Spain with forged documents; ${ }^{55}$ France sued in vain in Italian courts for the return of stolen and illegally exported tapestries, ${ }^{56}$ and in Germany, an insurance contract covering smuggled Nigerian artifacts was held immoral and therefore invalid. ${ }^{57}$

\subsection{Solutions by national rules of international commerce}

\subsubsection{Enforcement of foreign export prohibitions}

Up to now all courts have declined to enforce foreign export prohibitions, arguing that this would be enforcing foreign public law. The British House of Lords confirmed this position in Attorney General of New Zealand v. Ortiz, ${ }^{58}$ and therefore, in a subsequent case, the Kingdom of Spain did not sue for return of a smuggled Goya painting but asked for a declaratory judgment that the Spanish export documents had been forged. ${ }^{59}$ The judgment prevented Christie's from selling the painting in a public auction.

Similarly, an Italian court declined to enforce French export restrictions. ${ }^{60}$ In the United States, courts have applied American law when dealing with smuggled cultural objects, either confirming the violation of American import regulations, ${ }^{61}$ applying the National Stolen Property Act, ${ }^{62}$ or enforcing American treaty obligations so as to prevent the import of foreign cultural objects if not accompanied by a foreign export licence. ${ }^{63}$

\subsubsection{Enforcement of illegal contracts}

Contracts concerning the smuggling of cultural objects or the insurance of smuggled goods have been held invalid as immoral transactions. ${ }^{64}$ In most cases, however, no claim in contractual liability is initiated because such a claim normally does not entitle a party to 
recover the smuggled object. On the other hand, contract law may be helpful when the country of origin brings suit to recover the object, if the contract did not transfer title and the original owner can recover the object. This happened in the Italian Danusso case, ${ }^{65}$ in which Pre-Columbian unmerchantable artefacts were sold in Ecuador and therefore no title was transferred to the purchaser. Hence, the State of Ecuador could recover the cultural objects illegally exported by the purchaser to Italy.

\subsubsection{Intermediate summary}

Under national rules of international commerce, foreign export prohibitions are not enforced. Every State is required to enforce its own export regulations to the extent possible. An unlawfully exported cultural object can be recovered only if the plaintiff is still the owner of the object. This could be proven in the Italian Danusso case, ${ }^{66}$ and the plaintiff did not have to rely on Ecuadorian export regulations which would not have been enforced in Italy. Therefore, international instruments are necessary for the enforcement of foreign export regulations.

\subsection{Solutions under European law of international commerce}

Article 36 of the Treaty of Rome ${ }^{67}$ Establishing the European Economic Community provides:

The provisions of Arts. 30 to 34 [on freedom of movement of goods] shall not preclude prohibitions or restrictions on imports, exports or goods in transit justified on grounds of public morality, public policy or public security; the protection of health and life of humans, animals or plants; the protection of national treasures possessing artistic, historic or archaeological value; or the protection of industrial and commercial property. Such prohibitions or restrictions shall not, however, constitute a means of arbitrary discrimination or a disguised restriction on trade between Member States. [italics added by the author]

This exception from the principle of free movement of goods preserved national restrictions for the exportation of cultural property from violating the Rome Treaty. Hence, these national export restrictions remained valid and were applied by national authorities but gave no occasion for any proceedings in the European Court of Justice in which the notion "national treasure" had to be defined or delimited. ${ }^{68}$

When the European Internal Market was to be introduced on 1 January 1993 and national customs borders within the European Community were about to vanish, the European Member States with 
a rich cultural past (source states) were anxious to preserve the status quo and even to oblige the other Member States to enforce foreign restrictions on the free movement of cultural property. The results of this initiative were two European instruments: the Regulation of 9 December 1992 and the Directive of 15 March 1993. The more important of the two is the Directive.

\subsubsection{European Directive of 15 March 1993}

The European Directive 93/7/EEC of 15 March 1993 on the return of cultural objects unlawfully removed from the territory of a Member State ${ }^{69}$ obliges the Member States of the European Communities to implement the Directive by introducing national provisions necessary to comply with the provisions of the Directive.

The Directive requires Member States to return cultural objects unlawfully removed from the territory of another Member State. This goal is achieved by several provisions:

- Member States as requesting States may bring a suit against the possessor or holder of an object removed unlawfully from their territory (Article 3). ${ }^{70}$

- Suit must be brought in the requested Member State where the object is located (Article 3).

- The object to be returned must qualify as a "cultural object" within the definition of Article 1 (1); that is,

(i) it must be a "national treasure" within the meaning of Article 36 of the Rome Treaty;

(ii) it must be a "national treasure possessing artistic, historic or archaeological value" under national legislation of the requesting Member State; and

(iii) it must belong to one of the categories listed in the Annex to the Directive or must form an integral and inventoried part of public collections or ecclesiastical institutions.

- The cultural object must have been unlawfully removed on or after I January 1993 from the territory of the requesting Member State in breach of its rules on the protection of national treasures or in breach of Regulation (EEC) No. 3911/92, or the cultural object must not have been returned at the end of a period of lawful temporary removal (Articles 3 (2), 13).

- The proceedings for restitution must have been brought in time (Article 7).

- The possessor obliged to return the object must be compensated by the requesting Member State if the possessor exercised due care and attention in acquiring the object (Article 9).

The Directive does not regulate the following matters. The Directive itself does not protect cultural objects; it seeks only to introduce the extraterritorial enforcement of national protection policies. The 
Directive does not preclude civil proceedings for the restitution of stolen cultural objects (Article 15). Finally, the Directive does not change national rules on movable property, either domestic rules or conflicts provisions (Article 12).

The Directive of 15 March 1993 will have a significant impact on proceedings for the return of illegally exported cultural objects in European courts. For example, one may compare the outcome of the Italian-French controversy decided in the Italian De Contessini case. ${ }^{71}$ If the Directive and implementing Italian legislation had already been in force when the French tapestries were illegally exported to Italy, the French Republic as the plaintiff would have been successful. The bona fide purchaser De Contessini could not have pleaded that he had acquired good title by bona fide purchase and that he was therefore not obliged to return the object. He could not have argued that Italian courts do not enforce French public law prohibiting the movement of cultural objects from French territory. The bona fide defendant could only have asked the court to award compensation in exchange for his return of the objects. This example clearly shows that European national courts need to change their practice in at least two respects. First, full title in foreign cultural objects (i. e., without any obligation to return them) cannot be acquired bona fide, and, second, prohibitions of Member States of the European Union on the removal of cultural objects from their territory must be enforced by other Member States.

It may be questionable whether the Directive is compatible with the Rome Treaty of 1957. It more or less "constitutes ... a disguised restriction on trade between Member States" as forbidden under Article 36 sentence 2 of the Treaty and it may violate the basic European freedom of movement of persons. ${ }^{72}$

\subsubsection{European Regulation of 9 December 1992}

European Council Regulation (EEC) No. $3911 / 92$ of 9 December 1992 on the export of cultural goods ${ }^{73}$ has been directly applicable since 30 March 1993. ${ }^{74}$ This regulation requires an export licence for the export of cultural goods from a Member State to a third country (Article 2). The issuance of an export licence is not regulated by community law but is left to the Member States. According to Article 2 (3) of the Regulation, the "export licence shall be issued at the request of the person concerned by the competent authorities of the Member State on whose territory the cultural object in question was lawfully and definitely located on 1 January 1993, or, thereafter, on whose territory it is located following lawful and definitive export from another Member State."

An example may illustrate the working of the Regulation No. $3911 / 92$. If in the Italian De Contessini case ${ }^{75}$ the French tapestries had been smuggled to Italy after 1 January 1993 and the Italian bona 
fide purchaser wanted to export the objects to the United States, the French authorities would have been competent to decide whether an export licence should be issued. The Italian authorities would not have been competent because the tapestries which were illegally removed from France were located in Italy unlawfully. This example clearly shows that Regulation No. 3911/92 does not formulate a common European policy of export trade in cultural goods with third countries. Rather, it "Europeanizes" national export policies. The Regulation takes account of the extreme differences in national policies in the protection of cultural heritage and wants to ensure that cultural objects are not removed from those Member States with a very restrictive art trade policy to liberal Member States from which the objects can be easily exported. The only condition formulated by European law relates to the notion of cultural property (Article 1). The objects for which an export licence is required must qualify under one of the categories listed in the Annex to the Regulation which is identical with the Annex of the Directive of 15 March 1993. Apart from this Annex, it is left to the discretion of every Member State as to whether the export of such items should be restricted.

\subsubsection{Intermediate summary}

European law still upholds an exception for cultural objects from the principle of free movement of goods within Member States. The Member States are allowed to prohibit the removal of cultural objects from their territory and to enforce these prohibitions by bringing suits for return of the illegally removed objects in law courts of any Member State where the object is located. As a common export regulation for trade with third countries, the European Union wants to ensure that no cultural object protected by any Member State will be exported without an export licence issued by the country of lawful location.

\subsection{Solutions of international conventions on international commerce}

\subsubsection{Hague Convention of 1954}

Under the Hague Convention of 14 May 1954 for the Protection of Cultural Property in the Event of Armed Conflict, ${ }^{76}$ the High Contracting Parties "undertake to respect cultural property" (Article 4 (1)) and "to prohibit, prevent and, if necessary, put a stop to any form of theft, pillage or misappropriation of ... cultural property" (Article 4 (3)). In the Protocol to this Convention, ${ }^{77}$ the High Contracting Parties undertake "to prevent the exportation ... of cultural property" (I (1)). All of this has been reasonably interpreted as an obligation to return illegally exported cultural-objects. ${ }^{78}$ 


\subsubsection{UNESCO Convention of 1970}

The UNESCO Convention of 14 November 1970 on the Means of Prohibiting and Preventing the Illicit Import, Export and Transfer of Ownership of Cultural Property ${ }^{79}$ obliges the States Parties

to take the necessary measures, consistent with national legislation, to prevent museums and similar institutions within their territories from acquiring cultural property originating in another State Party which has been illegally exported after entry into force of this Convention, in the States concerned (Article 7 (a)).

If illegally exported art objects are found within the territory of a State Party, every State Party undertakes

at the request of the State Party of origin, to take appropriate steps to recover and return any such cultural property imported after the entry into force of this Convention in both States concerned, provided, however, that the requesting State shall pay just compensation to an innocent purchaser or to a person who has valid title to that property (Article 7 (b)(ii)).

There are, as yet, no court decisions which have ordered the return of cultural objects based on the UNESCO Convention. ${ }^{80}$ In the Italian De Contessini case, ${ }^{81}$ the Italian court declined to apply the Convention because it had not been implemented by the Italian legislature; in the Canadian case $R$. v. Heller, ${ }^{82}$ the Convention was held not applicable. In the German Nigeria case, ${ }^{83}$ the Convention, although not then and, up to now, still not ratified by Germany, was invoked in order to justify the conclusion that insurance contracts with regard to the transportation of smuggled art objects are immoral and void. The art objects themselves were lost and could not be recovered.

\subsubsection{Unidroit Convention of 1995}

The Unidroit Convention of 24 June 1995 on Stolen or Illegally Exported Cultural Objects ${ }^{84}$ has been prepared to remedy a few deficiencies of the UNESCO Convention of $1970 .{ }^{85}$ The new convention applies also to "claims of an international character for the return of cultural objects removed from the territory of a Contracting State contrary to its law regulating the export of cultural objects for the purpose of protecting its cultural heritage" (Article 1(b)).

In order to achieve such a return, a Contracting State may request the court or other competent authority of another Contracting State where the cultural object is located (Article 8) to order the return of a cultural object illegally exported from the territory of the requesting State (Article $5(1)$ ). Such a request will be successful if:

- the export was and still is prohibited by the requesting State (Articles 5 and 7); 
- no export license was issued;

- specific interests or a general interest of the requesting State in preserving objects of significant cultural importance are impaired (Article 5 (3));

- the request is brought in time (three years from the time when the requesting State knew the location of the object and the identity of its possessor, and in any case, within fifty years from the date of the illegal export) (Article 5 (4)), and

- reasonable compensation is offered to a bona fide possessor (Article $6(1)$ ) or any equivalent advantage.

If the Unidroit Convention had already been in force between the United Kingdom and New Zealand, the House of Lords would have had to decide the case Attorney General of New Zealand $v$. Ortiz ${ }^{86}$ differently. In this case, Maori artifacts were illegally exported from the territory of New Zealand and the owner, who was domiciled in Switzerland, consigned them for auction at Sotheby's in London. The Attorney General of New Zealand failed to convince the House of Lords that the export prohibitions of New Zealand should be enforced "extraterritorially" in the United Kingdom. Under the Unidroit Convention, the House of Lords would have had to return the Maori carvings if they had been exported from the territory of New Zealand after the date of the entry into force of the Convention in New Zealand and in the United Kingdom (Article 10 (2)) and if the carvings were of "significant cultural importance" for New Zealand (Article 5(3) last part). ${ }^{87}$ Thus the Unidroit Convention (as is the case with the European Directive of 1993) ${ }^{88}$ enforces export regulations of a foreign Contracting State.

\subsubsection{Conventions of legal assistance in matters of criminal law}

Apart from the conventions already mentioned, there are no special international instruments on legal assistance for the recovery of illegally exported cultural objects. The general treaties for legal assistance may, however, be applied in cases of smuggling of cultural objects. This was done in Italian-Swiss relations. An Etruscan tombstone was illegally exported from Italy to Switzerland and Italy asked Switzerland to provide this object as evidence for the criminal trial in Italy. Switzerland granted legal assistance and permitted the tombstone to be returned temporarily to Italy for the trial. ${ }^{89}$

\subsection{Solutions by international codes of conduct}

Even if no international instruments govern the dispute, codes of professional conduct may have the same or similar effect as international conventions or treaties. This happened in the English case, Kingdom of Spain v. Christie, Manson \& Woods Ltd. ${ }^{90}$ As previously mentioned, the Goya painting La Marquesa de Santa Cruz was illegally exported from the territory of Spain and was to be auctioned 
in London with Christie's. When the Spanish government learned of the forthcoming auction, it applied for a judicial declaration that the Spanish export licences had been forged. This was the only remedy available as the Spanish government knew that, after the decision in The Attorney General of New Zealand v. Ortiz, ${ }^{91}$ English courts would not enforce foreign export regulations. Christie's withdrew the Goya painting from the scheduled auction because of codes of conduct which ban the trade in illegally exported cultural objects. Finally, Spain bought the painting for $\$ 6$ million and exhibits it in the Prado where it can be admired.

\subsection{Intermediate Summary}

Under national conflict law, foreign export prohibitions are not enforced because no State is ready to enforce foreign public law or to assist foreign States in their policy regarding their cultural treasures. The EC Directive of 15 March $1993^{92}$ obliges all member States of the European Union to enforce "export" prohibitions of foreign Member States. The same is true according to the Unidroit Convention $^{93}$ as to export regulations of Contracting States of this instrument. Codes of conduct may stop an auction but will not oblige the return of an art object.

\section{International Commerce in Unmerchantable Cultural Objects (res extra commercium)}

In some States, several cultural objects are qualified as unmerchantable objects, res extra commercium, which cannot be sold and which are not subject to acquisitive prescription, laches or statutes of limitations. ${ }^{94}$ If such objects are traded, this restrictive policy may be enforced within the borders of the State pursuing such a policy. If the objects are sold abroad, however, States will not recognize any foreign limitation on trade in movables. ${ }^{95}$ Such a recognition will only be granted according to international conventions. Because such objects which are res extra commercium should not be exported, their movement across State borders will be governed by the EC Directive of 15 March $1993^{96}$ and the Unidroit Convention. ${ }^{97}$

In 1883, a Spanish ciborium of the Cathedral of Burgos, which was considered unmerchantable under Spanish law, was sold in France. Spain claimed the ciborium, alleging that the sale of an unmerchantable object was void. The Tribunal de la Seine rejected this claim because French law did not recognize the Spanish qualification as res extra commericum. ${ }^{98}$ If this case were to occur today, the purchaser would have to return the ciborium under the EC Directive of 15 March $1993^{99}$ as Spanish cultural property illegally exported from the territory of Spain. If it were stolen, such unmerchantable objects would even have a special status under the Unidroit Convention with regard to time limitations for a claim of restitution (Article 3 (5)). 


\section{Protection of Cultural Property: Policies, Trends and Solutions}

On the national level, cultural objects are protected by collectors, museums and different State agencies on the local, intermediate and upper level. Diminishing budgets for cultural purposes lead to less protection of cultural goods: archaeological sites are not supervised; museums are not properly kept in order to prevent physical damage, thefts or misappropriations; customs control is inefficient or does not exist anymore. In short, cultural objects are in danger. National mismanagement cannot be eliminated by international law. National conflicts rules and international instruments can only try to cope with serious problems regarding objects of considerable value. Such international obligations will be assumed and performed. But let us not forget-we should respect foreign cultural treasures wherever they are and whoever their owners may be.

On the other hand, I am not quite sure whether the current wave of cultural nationalism, as reflected even within the European Union and in the European Directive, will or even must not come to naught before long. The preservation of cultural property is very expensive, and not every source nation can afford an efficient museum and site strategy. Without a reasonable international cooperation, exchange, lending and even sale policy, we may be at a cross-roads very soon between national acquisitiveness, even at the expense of destruction and seclusion, and international cooperation, assistance and accessible preservation for future generations. ${ }^{100}$

\section{Notes}

1 See S. V. Reit, The Day They Stole the Mona lisa 17 et seq. (London 1981); A. Chastel, L'illustre INCOMPRISE 37 et seq. (Paris 1988); M. VanNuCCI, Il fURto della Gioconda. Vincenzo Peruggia E la sUa STORIA 11 et seq. (Palermo 1993).

2 Tribunale Firenze of 2 June 1914; Ragguagli giuridici 1914, col. 563, with annotation by T. De Bacci Venuti = Repertorio del Foro italiano 1914, col. 100 , no. 15.

3 Tribunale di Roma of 27 June 1987 (Stato francese c. Ministero per i beni culturali e ambientali e De Contessini), 71 RIVISTA DI DIRITTO INTERNAZIONALE 920 (1988), confirmed by Corte di Cassazione of 24 November 1995 , n. 12166, 33 Rivista di diritto internazionale e processuale 427 (1997).

4 DeWeerth v. Baldinger, 658 F. Supp. 688 (S. D. N. Y. 1987), 836 F.2d 103 (2d Cir. 1987), relief granted under Rule 60 F. R. C. P., 804 F. Supp. 539 (S. D. N. Y. 1992), rev'd, 38 F.3d 1266 (2d Cir. 1994).

5 Oberlandesgericht Schleswig of 10 February 1989, 1989 Neue Juristische Wochenschrift $3105=$ Deutsche Rechtsprechung auf dem Gebiet des Internationalen Privatrechts im Jahre 1989 no. 75.

6 Bundesgericht of 6 February 1985 (Staat Italien gegen X und Appellationsgericht des Kantons Basel-Stadt), 111 Entscheidungen des Schweizerischen Bundesgerichts part I a, p. 52. 
7 Bundesgericht of 22 May 1996 (Türkische Republik gegen Kanton Basel Stadt und Peter Ludwig) (still unpublished).

8 See Watson, Sotheby's Inside Story 113 et seq. (London 1997).

9 Government of Peru v. Johnson, 720 F. Supp. 810 (C.D. Calif.), aff'd, 933 F.2d 1013 (9th Cir. 1989); United States v. McClain, 545 F.2d 988 (5th Cir. 1977), 593 F.2d 658 (5th Cir. 1979). As to the first case, see John Henry Merryman, Limits on State Recovery of Stolen Artifacts: Peru v. Johnson, 1 INT'L J. Cult. Prop. 169 et seq. (1992).

10 See J. Greenfield, The Return of Cultural Treasures 305-07 (2d ed., Cambridge 1996).

11 Republic of Lebanon v. Sotheby's, 561 N.Y.S.2d 566 (N.Y. App. Div. 1990); Bennett, Conserving the SEVSO Treasure, 6 MINERVA no. 1, 50 (1995); D. D'Arcy, The Sevso melodrama - who did what to whom, THE ART NewSPAPER, Oct. 1993, at 14.

12 See G. C. Venturini, Property, in InTERnational EnCyClopedia of COMParative LaW, Vol. IIl, chapter 21, p. 21-2 (Tübingen 1976).

13 Winkworth v. Christie, Manson \& Woods Ltd., [1980] 1 All E.R. 1121, [1980] 2 W. L. R. 937 (Ch. D.).

14 A. DucheK \& F. Schwind, Internationales Privatrecht 78 (note 3 to $\S 31$ IPR-Gesetz) (Vienna 1979).

15 L. STRIKWERDa, INLEIDING TOT HET NEDERLANDSE INTERNATIONAAL PRIVAATRECHT 159-60 (4th ed. Groningen 1995); R. VAN ROOIJ \& M. V. Polak, Private International LaW in the Netherlands 161 (Deventer 1987) and Supp. 94 (1995).

16 Bundesgerichtshof of 20 March 1963, 39 Entscheidungen des Bundesgerichtshofs in Zivilsachen 173 (French registered security interest); Oberlandesgericht Hamburg of 2 June 1965: 32 Rabels Zeitschrift für ausländisches und internationales Privatrecht $535(1968)=$ Die deutsche Rechtsprechung auf dem Gebiete des internationalen Privatrechts in den Jahren 1964 und 1965, no. 73 (English reservation of the right of disposal); K. KreuZer, 7 Münchener Kommentar zum BGB, Nach Art. 38 Anh. I, marginal note 62 (2d ed., 1990).

17 See T. Ballarino, Diritto internazionale privato 559 (2d ed., Padova 1996); P. Benvenuti, Comment to Article 51 of the New Italian Statute on Private International Law of 1995, 19 LE NUOVE LEGGI CIVILI COMMENTATE 1325, 1334 (1996); R. Luzzatto, Comment to Art. 51 of the new Italian Statute on Private International Law of 1995, 31 RIVISTA DI DIRITTO INTERNAZIONALE PRIVATO E PROCESSUALE 1157 (1995).

18 M. BOGDAN, SVENSK INTERNATIONELL PRIVAT- OCH PROCESSRÄTT 263 (4th ed., Stockholm 1992).

19 Virgos Soriano, in J. Gonzales Campos et al., Derecho Internacional Privado. Parte especial, p. 366 (5th ed., Madrid 1993).

20 Bundesgericht of 13 December 1963, 94 Entscheidungen des Schweizerischen Bundesgerichts part II, 297, 303-05 (German security transfer of movables); unchanged by the new P.I.L. Statute of 1987; see Heini in IPRG KOMMENTAR 810 (Zürich 1993) marginal note 12 to Art. 100 IPRG. French law differs in this respect (application of the new lex rei sitae and application of former facts according to the new law), Cour de Paris of 14 December 1883 (Benedetti, Segré et Cie. c. Bazzi), 10 Clunet 631 (1883); H. BATIFFol \& P. Lagarde, 2 Droit international PRivé 173 (7th ed., Paris 1983); B. Audit, DroIT INTERNATIONAL PRIVÉ 594 (Paris 1991); Y. LousSouarn \& P. Bourel, Droit international Privé 442 (4th ed., Paris 1993). 
21 This is sometimes done in various American states where such remedies are qualified as procedural rules governed by the lex fori. See E. F. Scoles \& P. Hay, Conflict of Laws 58 et seq. (2d ed., St. Paul, Minn. 1992).

22 They qualify such remedies as those of substantive law. See D. GiRSBERGER, VERJÄHRUNG UND VERWIRKUNG IM INTERNATIONALEN OBLIGATIONENRECHT 46 (Zürich 1989).

23 DeWeerth v. Baldinger, 658 F. Supp. 688 (S.D.N.Y. 1987), 836 F.2d 103 (2d Cir. 1987), relief granted under Rule 60 F. R. C. P., 804 F. Supp. 539 (S.D.N.Y. 1992), rev'd, 38 F.3d 1266 (2d Cir. 1994). [However, the court's use of the discovery rule to bar the plaintiff's claim was subsequently disapproved by the New York Court of Appeals in Guggenheim v. Lubell, 77 N.Y.2d 311, 569 N.E.2d 426, 567 N.Y.S.2d 632 (1991). As a result, the holding in DeWeerth has no precedential value.-Ed.'s note].

24 Bundesgericht of 13 December 1963, supra note 20.

25 National Stolen Property Act, 18 U. S. Code $\S 2315$ (1).

26 United States v. McClain, 545 F.2d 588 (5th Cir. 1977), 593 F.2d 658 (5th Cir. 1979).

27 See Article 1 of the Greek Act No. 5351 of 9 August 1932 on Antiquities, in Beni Culturali E MerCato europeo 135 (A. Maresca Compagna \& P. Petraroia eds., Rome 1991).

28 See Article 44 of the Italian Act No. 1089, 1 June 1939 on the Protection of Objects of Cultural and Historical Interest, in BENI CULTURALI E MERCATO EUROPEO 232 (A. Maresca Compagna \& P. Petraroia eds., Rome 1991).

29 See, e. g., Article 10(2) Luxemburg Act of 18 July 1983 on the conservation and protection of sites and national monuments, MÉmORIAL A 1983, p. 1390.

30 Attorney General of New Zealand v. Ortiz, [1982] 2 W.L.R. 10 (Q.B.), [1984] 1 A.C. 1 (C.A., H.L.).

31 Article 28 Hague Convention of 18 October 1907 Concerning the Law and Customs of War, 205 Consolidated Treaty Series 277.

32 Article 4(3) of the Hague Convention of 14 May 1954 for the Protection of Cultural Property in the Event of Armed Conflict, 249 U.N.T.S. 216, 240.

33823 U.N.T.S. 231, 10 I.L.M. 289 (1971).

34 Cultural Property Implementation Act, 19 U. S. C. $\S \S 2601,2607$ (1988).

35 Reprinted in 1 UNIFORM L. REv. N. S. 110 (1996), 1 ART ANTIQUITY AND LAW 79 (1996); 5 INT'l J. CUlt. Prop. 155 (1996), 95 ZeItSChrift Für VERGLEICHENDE RECHTSWISSENSCHAFT 203 (1996).

36 Tribunale di Roma of 27 June 1987 (Stato francese c. Ministero per i beni culturali e ambientali e De Contessini), 71 RIvisTa DI DIRITTO INTERNAZIoNALE 920 (1988), confirmed by Corte di Cassazione of 24 November 1995, n. 12166,33 RIVISTA DI DIRITTO INTERNAZIONALE PRIVATO E PROCESSUALE 427 (1997).

37 Winkworth v. Christie, Manson \& Woods Ltd., [1980] I All E.R. 1121, [1980] 2 W.L.R. 937 (Ch. D.).

38 This was already suggested by counsel of the plaintiff in Winkworth v. Christie, Manson \& Woods Ltd., [1980] 1 All E.R. at 1133.

39 See, e. g., European Convention of 20 April 1959 on Mutual Assistance in Criminal Matters, Europ. T.S. No. 30, 472 U.N.T.S. 185.

40 Id. Art. 6 (2). Request granted by the Swiss Federal Court of 1 April 1997, 123 Arrêts du Tribunal Fédéral Suisse, part II, p. 134.

41 Oberlandesgericht Schleswig of 10 February 1989, supra note 5. 
42 Supra note 27.

43 Europ. T.S. No. 143.

44 The Convention is (as of 1 February 1997) in force in ten States: Bulgaria, Finland, France, Hungary, Liechtenstein, Malta, Norway, Poland, Sweden and Switzerland. The predecessor European Convention of 6 May 1969 on the Protection of the Archaeological Heritage (Europ. T.S. No. 66) is in force (as of 1 February 1997) in about twenty other States and successor States of former States Parties (the Soviet Union and Yugoslavia).

45 Article 10(3), supra note 43, which is similar to Article 6(2)(a) of the 1969 Convention, supra note 44.

46 See the Buenos Aires Draft and the comments to it, RePORT OF THE SiXTYSixth Conference Held at Buenos Aires, Argentina 1994, 15 and 432 (ILA ed., Buenos Aires 1994); see also James A. R. Nafziger, The Buenos Aires Draft Convention on the Protection of the Underwater Cultural Heritage, 6 INT'L J. CULt. Prop. 119-27 (1997).

47 See A. Strati, The Protection of the Underwater Cultural HeriTAGE: AN EMERgING OBJeCtive OF THE CONTEMPORARY LAW OF THE SEA (The Hague, London, Boston 1995).

48 As to this Institute, see LIVRE DU CENTENAIRE 1873-1973 - Evolution ET PERSPECTIVES DU DROIT INTERNATIONAL (Institut de Droit international ed., Basle 1973).

49 The international sale of works of art from the angle of the protection of the cultural heritage, 64 YEARBOOK OF THE INSTITUTE OF INTERNATIONAL LAW, part II, 403 (1992), and this Journal infra p. 376 with introduction by E. Jayme. As to this Resolution, see E. Jayme, Neue Anknüpfungsmaximen für den Kulturgüterschutz im internationalen Privatrecht, in RECHTSFRAGEN DES INTERNATIONALEN KULTURGÜTERSCHUTZES 35-52 (R. Dolzer, E. Jayme \& R. Mußgnug eds., Heidelberg 1994), and in ÉTUDES DE DROIT INTERNATIONAL EN L'HONNEUR DE PIERRE LALIVE 717 et seq. (Basle 1995).

50 Tribunale di Roma of 27 June 1987 (Stato francese c. Ministero per i beni culturali e ambientali e De Contessini), 71 RIVISTA DI DIRITTO INTERNAZIONALE 920 (1988), confirmed by Corte di Cassazione of 24 November 1995, n. 12166, 33 RIVISTA DI DIRITTO INTERNAZIONALE PRIVATO E PROCESSUALE 427 (1997).

51 See The Berlin Declaration of 1988, AKTEN DES XIII INTERNATIONALEN KONGRESSES FÜR KLASSISCHE ARCHÄOLOGIE 642 (Deutsches Archäologisches Institut ed., Berlin 1988, Mainz 1990).

52 See L. V. Prott \& P. J. O'Keefe, Manuel des règlements nationales relatives à l'exportation des biens culturels, UNESCO (1988).

53 See A. Bertolotti, Die Ausfuhr einiger Gegenstände aus Rom nach Österreich, Deutschland, Polen und Russland vom 16. bis 19. Jahrhundert, in 5 REPERTORIUM DER KUNSTWISSENSCHAFT 371 et seq. (1882).

54 Attorney General of New Zealand v. Ortiz, [1982] 2 W.L.R. 10 (Q. B.), [1984] 1 A.C. 1 (C.A., H.L.).

55 Kingdom of Spain v. Christie, Manson \& Woods Ltd., [1986] 1 W.L.R. 1120 (Ch. D.). As to this case and an illustration of the painting, see J. Agnew \& M. Farrer, Goya's “The Marquesa De Santa Cruz," 1 INT'L J. Cult. PROP. 137 et seq. (1992).

56 Tribunale di Roma of 27 June 1987 (Stato francese c. Ministero per I beni culturali e ambientali e De Contessini), 71 RIVISTA DI DIRITTO INTERNAZIONALE 920 (1988), confirmed by Corte di Cassazione of 24 November 1995, n. 12166, 33 RIVISTA DI DIRITTO INTERNAZIONALE PRIVATO E PROCESSUALE 427 (1997). 
57 Bundesgerichtshof of 22 June 1972, 59 Entscheidungen des Bundesgerichtshofes in Zivilsachen 82 (1972), 73 1.L.R. 226 (1972) .

58 Attorney General of New Zealand v. Ortiz, [1982] 2 W.L.R. 10 (Q. B.), [1984] 1 A.C. 1 (C.A., H.L.).

59 Kingdom of Spain v. Christie, Manson \& Woods Ltd., [1986] 1 W.L.R. 1120 (Ch. D.).

60 Tribunale di Roma of 27 June 1987 (Stato francese c. Ministero per i beni culturali e ambientali e De Contessini), 71 RIVISTA DI DIRITTO INTERNAZIONALE 920 (1988), confirmed by Corte di Cassazione of 24 November 1995, n. 12166,33 RIVISTA DI DIRITTO INTERNAZIONALE PRIVATO E PROCESSUALE 427 (1997).

61 United States v. One Tintoretto Painting, 527 F. Supp. 1071 (S.D.N.Y. 1981).

62 United States v. McClain, 545 F.2d 988 (5th Cir. 1977), 593 F.2d 658 (5th Cir. 1979).

63 See the Cultural Property Implementation Act, 19 U. S. C. $\S 2601$ et seq. (1988).

64 Bundesgerichtshof of 22 June 1972, 59 Entscheidungen des Bundesgerichtshofes in Zivilsachen 82 (1972), 73 I.L.R. 226 (1972) (the so-called "Nigeria case").

65 Tribunale di Torino of 23 March 1982 (Casa della cultura ecuadoriana c. Danusso), 18 RIVISTA DI DIRITTO INTERNAZIONALE PRIVATO E PROCESSUALE 625 (1982).

66 Id.

67 Treaty of 25 March 1957 Establishing the European Community, 298 U.N.T.S. 11; current version in ENCYCLOPEDIA OF EUROPEAN COMMUNITY LAW, vol. B, para. B 10 (London, loose-leaf 1996).

68 See European Court of Justice 10 December 1968, case 18/71, E.C.R. 1968, at $633 ; 26$ October 1971 , case $18 / 71$, E.C.R. 1971, at $811 ; 13$ July 1972, case $48 / 71$, E.C.R. 1972, at 529.

69 Official Journal of THE European Communities [OJ] 1993 No. L 74/ 74, and this Journal infra p. 387. The 1992 Proposal to this Directive is reprinted, 1 INT'L J. Cult. Prop. 418 (1992). See also Council Directive 96/100/EEC of 17 February 1997 amending the Annex to the Directive 93/ 7/EEC, OJ 1997 No. L 60/59. As to the Directive 93/7/EEC, see the selection of studies written in English (most of the other studies are written in French, German, Italian or Spanish): F. François Rigaux, The Protection of cultural heritage. Aspects of EEC Law, in Kunsthandel (inclusief antiquiteiten) en de bescherming van nationaal cultureel erfgoed, 109 MEDEDELINGEN VAN DE NEDERLANDSE VERENIGING VOOR INTERNATIONAAL RECHT 67-98 (1994); E. Roberts, Cultural Policy in the European Community: A Case against Extensive National Retention, 28 TeXAS INT'L L. J. 191-228 (1993); K. A. Short, Preventing the Theft and Illegal Export of Art in a Europe without Borders, 26 VANDERBILT J. TRANSNAT'L L. 633-65 (1993); K. Siehr, International Protection of Cultural Property in the European Community, in ÉTUDES DE DROIT INTERNATIONAL EN L'HONNEUR DE Pierre Lalive 763-75 (Basle 1995).

70 According to Article 15 of the Directive, individuals are not precluded from bringing suit under normal rules of international litigation.

71 Tribunale di Roma of 27 June 1987 (Stato francese c. Ministero per i beni culturali e ambientali e De Contessini), 71 RIVISTA DI DIRITTO INTERNAZIONALE 920 (1988), confirmed by Corte di Cassazione of 24 November 1995, 
n. 12166, 33 RIVISTA DI DIRITTO INTERNAZIONALE PRIVATO E PROCESSUALE 427 (1997).

72 This is discussed by K. Siehr, Freizügigkeit und Kulturgüterschutz in der Europäischen Union, in FESTSCHRIFT FÜR ERNST-JOACHIM MESTMÄCKER 483 et seq. (Baden-Baden 1996).

73 O. J. 1992 No. L 395/1, and this Journal infra p. 379. The 1992 Proposal to this Regulation is reprinted in 1 Int'l J. Cult. Prop. 415 (1992). As to the literature discussing this regulation, see supra note 69 .

74 O. J. 1993 No. L 74/80.

75 Tribunale di Roma of 27 June 1987 (Stato francese c. Ministero per i beni culturali e ambientali e De Contessini), 71 RIVISTA DI DIRITro INTERNAZIONALE 920 (1988), confirmed by Corte di Cassazione of 24 November 1995 , n. 12166,33 RIVISTA DI DIRITTO INTERNAZIONALE PRIVATO E PROCESSUALE 427 (1997).

76 Supra note 32.

77 Protocol for the Protection of Cultural Property in the Event of Armed Conflict, in The Protection of Movable Cultural Propery, Vol. I, 352 (UNESCO ed., Paris 1984).

78 T. Fitschen, Licit International Art Trade in Times of Armed Conflict?, 5 InT'L J. Cult. Prop. 127-32 (1995); see also J. Toman, The Protection of Cultural Property in the Event of Armed Conflict 341 (Aldershot, Paris 1996).

79823 U.N.T.S. 231, 10 I.L.M. 289 (1971).

80 See K. Siehr, Völkerrecht und internationaler Kulturgüterschutz vor Gericht, in FESTSCHRIFT MüLLER-FreIENFELS 57 et seq. (Frankfurt a.M. 1996).

81 Tribunale di Roma of 27 June 1987 (Stato francese c. Ministero per i beni culturali e ambientali e De Contessini), 71 RIVISTA DI DIRITTO INTERNAZIONALE 920 (1988), confirmed by Corte di Cassazione of 24 November 1995, n. 12166, 33 RIVISTA DI DIRITTO INTERNAZIONALE PRIVATO E PROCESSUALE 427 (1997).

82 R. v. Heller, 27 Alberta Law Reports 2d 346 (1983), 51 Alberta Reports 73 (Q. B. 1984).

83 Bundesgerichtshof of 22 June 1972, 59 Entscheidungen des Bundesgerichtshofes in Zivilsachen 82, 73 I.L.R. 226.

84 Supra note 35.

85 Supra note 33.

86 Attorney General of New Zealand v. Ortiz, [1982] 2 W.L.R. 10 (Q. B.), [1984] 1 A.C. 1 (C.A., H.L.).

87 As to this precondition, see J. H. Merryman, The UNIDROIT Convention: Three Significant Departures from the Urtext, 5 INT'L J. CULT. Prop. 11, 15-16 (1996).

88 Supra note 69.

89 Bundesgericht of 6 February 1985 (Staat Italien gegen X und Appellationsgericht des Kanton Basel-Stadt), 111 Entscheidungen des Schweizerischen Bundesgerichts part I a, p. 52.

90 Kingdom of Spain v. Christie, Manson \& Woods Ltd., [1986] 1 W.L.R. 1120 (Ch. D.). See also supra note 55.

91 Attorney General of New Zealand v. Ortiz, [1982] 2 W.L.R. 10 (Q. B.), [1984] 1 A.C. 1 (C.A., H.L.).

92 Supra note 69.

93 Supra note 35.

94 See K. Siehr, Kulturgüter als res extra commercium im internationalen Rechtsverkehr, in LEBENDIGES RECHT - VON DEN SUMERERN BIS ZUR GEGENWART, FeSTCHRIFT REINHOLD TRINKNER 703 et seq. (Heidelberg 1995). 
95 See Tribunal de la Seine of 17 April 1885 (Duc de Frias c. Baron Pichon), 13 Clunet 593 (1886); Tribunale di Roma of 27 June 1987 (Stato francese c. Ministero per i beni culturali e ambientali e De Contessini), 71 RrvisTA DI DIRITTO INTERNAZIONALE 920 (1988), confirmed by Corte di Cassazione of 24 November 1995, n. 12166, 33 RIVISTA DI DIRITTO INTERNAZIONALE PRIVATO E PROCESSUALE 427 (1997).

96 Supra note 69.

97 Supra note 35.

98 Tribunal de la Seine of 17 April 1885 (Duc de Frias c. Baron Pichon), 13 Clunet 593 (1886).

99 Supra note 69.

100 See J. H. Merryman, Two Ways of Thinking about Cultural Property, 80 AM. J. INT'L L. 831 et seq. (1986); K. Siehr, International Art Trade and the Law, in 243 ReCUEIL DES COURS 9 et seq. and 252 et seq (1993-VI). 
